\title{
Erratum to: Intact cell mass spectrometry as a rapid and specific tool for the differentiation of toxic effects in cell-based ecotoxicological test systems
}

\author{
Sascha Liane Kober ${ }^{1}$ - Henriette Meyer-Alert ${ }^{2}$ Desirée Grienitz ${ }^{1} \cdot$ Henner Hollert $^{2,3,4,5}$. \\ Marcus Frohme ${ }^{1}$
}

Received: 28 October 2015 / Accepted: 28 October 2015 /Published online: 9 November 2015

(C) Springer-Verlag Berlin Heidelberg 2015

\section{Erratum to: Anal Bioanal Chem}

DOI: $10.1007 / \mathrm{s} 00216-015-8937-2$

The publisher regrets that in the original version of this article the units in the legend of Fig. $5 \mathrm{~b}$ and the greek charakter $\mu$ (micro) were incorrect. The correct version of Fig. 5 is given below.

Our sincere apologies to the authors.

The online version of the original article can be found at http://dx.doi.org/ $10.1007 / \mathrm{s} 00216-015-8937-2$.

Marcus Frohme

marcus.frohme@th-wildau.de

1 Molecular Biotechnology and Functional Genomics, Technical University of Applied Sciences Wildau, Hochschulring 1, 15745 Wildau, Germany

2 Institute for Environmental Research (Biology V), Department of Ecosystem Analysis, RWTH Aachen University, Worringerweg 1, 52056 Aachen, Germany

3 Key Laboratory of Yangtze River Water Environment, Ministry of Education, College of Environmental Science and Engineering, Tongji University, 1239 Siping Road, Shanghai 200092, China

4 College of Resources and Environmental Science, Chongqing University, Chongqing 400030, China

5 School of Environment, Nanjing University, 163 Xianlin Ave, Nanjing 210023, China 

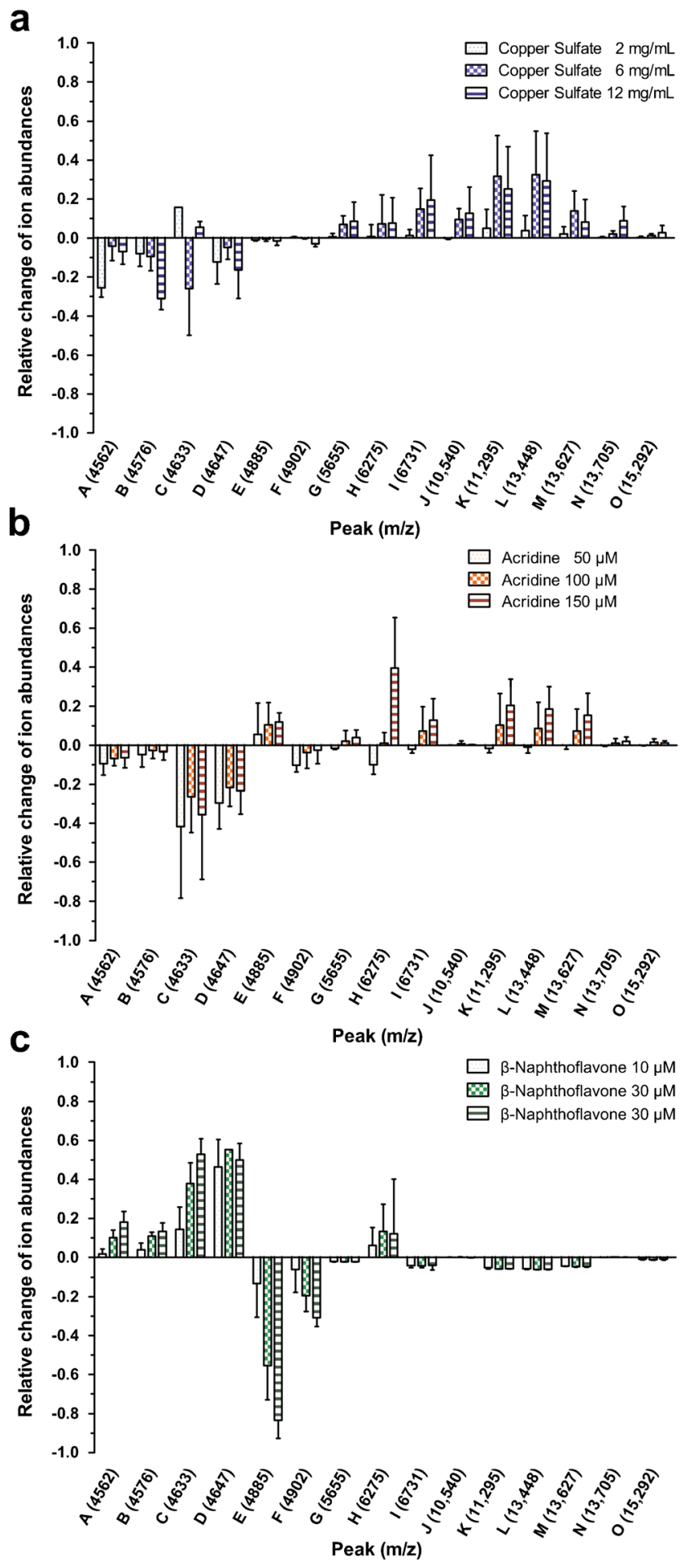

Fig. 5 Relative change of ion abundances of spectra of RTLW1 exposed to various concentrations of copper sulfate (a), acridine (b) and BNF (c) compared to the controls. Data are shown as means and standard deviations of six independent experiments 